\title{
Rockhopper penguins and other marine life threatened by driftnet fisheries at Tristan da Cunha
}

\author{
Peter G. Ryan and John Cooper
}

The oriental driftnet fleet, which is responsible for the large-scale mortality of non-target species in the Pacific Ocean, has extended its range to include the South Atlantic Ocean. Relatively little is known about the areas of operation and impacts of driftnetting in the South Atlantic as yet, but it is emerging that driftnetting is equally devastating to the fauna of this ocean. This paper reviews the impact of the driftnet fishery on non-target species in the central South Atlantic Ocean. Several lines of evidence suggest that fishing effort is focused on Tristan da Cunha, apparently resulting in considerable mortality of rockhopper penguins Eudyptes chrysocome and other marine organisms. Britain should take steps to curb this destructive fishing technique in Tristan waters.

Driftnet or gillnet fisheries based in oceanic waters have attracted considerable attention due in part to the unacceptably large bycatch of non-target species, including marine mammals, birds, turtles, and fish (e.g. King, 1984; Coffey and Grace, 1990; Gjernes et al., 1990). This concern is demonstrated by various steps taken internationally to counter driftnetting. For example, in October 1989 the Langkawi Declaration on Environment committed the Commonwealth Heads of Governments to seek to ban pelagic driftnet fishing (FAO, 1990). In December 1989 the United Nation's General Assembly adopted Resolution 44/225, which proposed an international moratorium on the use of high-seas driftnets by July 1992, and called for the immediate cessation of the spread of driftnet fisheries. Several South Pacific countries including Australia and New Zealand have closed their ports to driftnet operators, and have opened for signature the Convention for the Prohibition of Fishing with Long Driftnets in the South Pacific (FAO, 1990). However, despite the increasing international pressure, the oriental driftnet fleet, based primarily in Japan, South Korea and the Republic of China (Taiwan), has extended its area of operation from the Pacific Ocean to include the South Atlantic Ocean (Anon., 1989a; b).

Currently there are few data on the numbers of vessels, areas of operation, or impacts of driftnet fishing for tuna in the South Atlantic. A 1990 review provides no evidence on the use of driftnets in the South Atlantic (FAO, 1990), and the 1989 annual meeting of the International Commission for the Conservation of Atlantic Tuna (ICCAT) took no action on driftnets, despite the issue being raised by South African delegates (Anon., 1989a; FAO, 1990). Taiwanese vessels allegedly catch very little tuna with driftnets in the South Atlantic (Anon., 1989b), and Taiwanese officials have reportedly told their nationals not to use driftnets in the South Atlantic (Rice, 1990). However, exemption permits allowing approximately 160 Taiwanese vessels carrying driftnets to call at South African ports en route to the South Atlantic were issued in April 1990 (Rice, 1990), and while some of these may have been used solely in the Indian Ocean, there is reason for concern about the size of the driftnet fishery in the South Atlantic.

A crew member from a Taiwanese vessel reported that vessels crossing the South Atlantic to fish for squid (with jigging 
machines, not driftnets) off the Falkland Islands first spent a month driftnetting for tuna in the South Atlantic. The catch was trans-shipped at sea before continuing to the Falklands. Driftnetting took place after travelling southwest from Cape Town for 'about a week', and a mountain could be seen in the distance from the fishing grounds (The Argus, 21 June 1990, p. 11). This almost certainly pertains to the Tristan da Cunha group of islands or adjacent Gough Island, which comprise a British Dependency in the central South Atlantic Ocean.

Unequivocal evidence of driftnetting taking place close to Tristan and Gough was obtained during research cruises of the $R$. S. Africana in April 1989 and February 1990, when five oriental vessels were observed fishing within 200 nautical miles of the islands, and a further vessel was observed just beyond the 200 nautical mile economic exclusive zone (Figure 1). No vessels were observed using driftnets farther from the islands. On close inspection of the vessel 25 miles east of Gough Island on 27 April 1989, the Africana's propellor became entangled in driftnetting (B. Rose, Sea Fisheries Research Institute, pers. comm.). One of the vessels approached on 19 February 1990, the Tuesinn Ying No. 1, was seen to have eight dead rockhopper penguins Eudyptes chrysocome floating in the water behind the vessel, apparently having been dumped after drowning in driftnets (R. Leslie, Sea Fisheries Research Institute, pers. comm.).

These observations support the report of the crew member from the Taiwanese vessel thought to be operating in the Tristan area. He reported that during a month of driftnetting for albacore (longfin tuna) Thunnus alalunga, the bycatch included 'many' penguins, as well as 15-20 dolphins, 3-4 small whales, sunfish Mola mola, 'lots' of sharks, and other fish (The

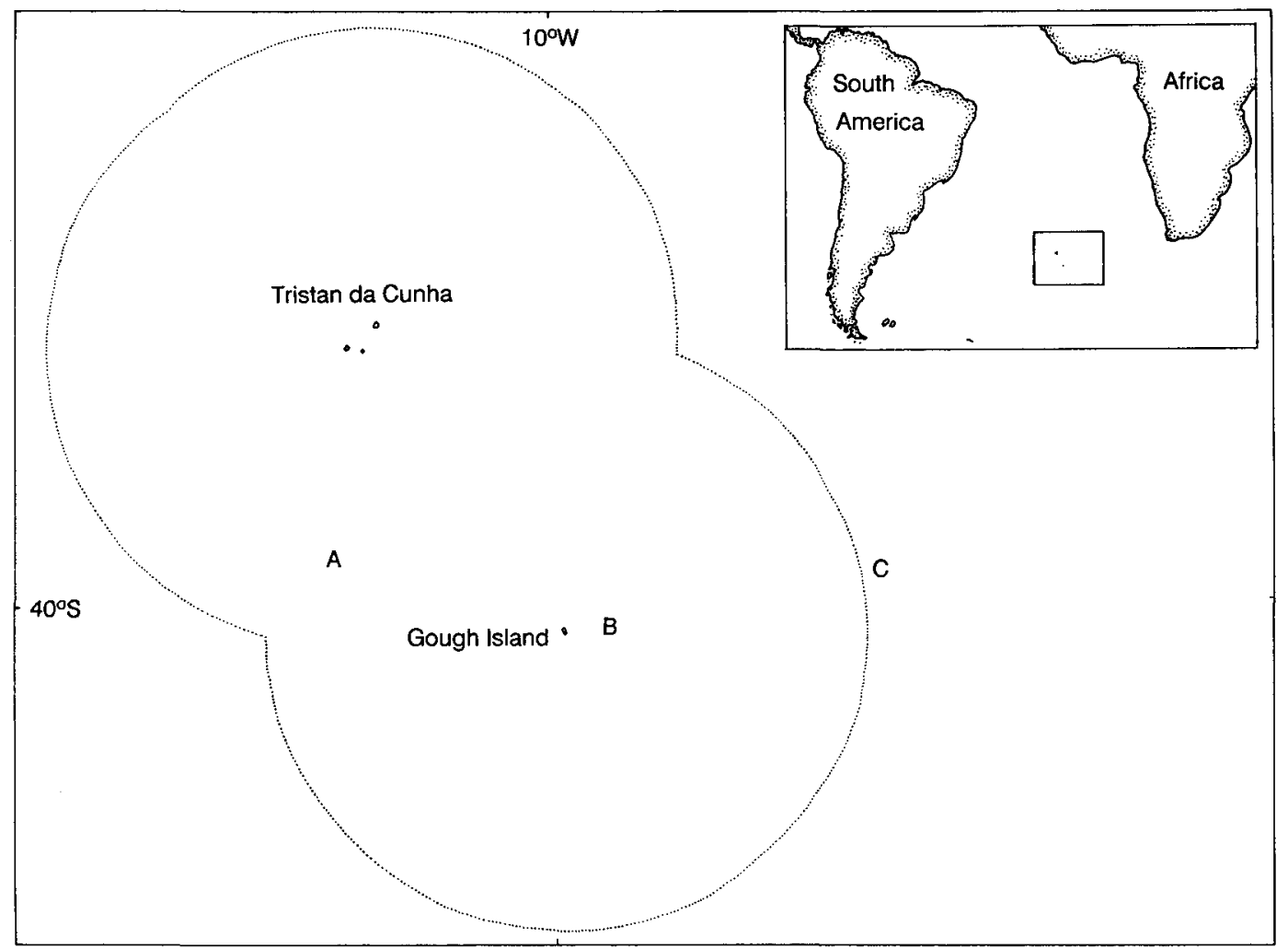

Figure 1. Sightings of vessels driftnetting around the Tristan da Cunha group of islands. A, a group of four boats on 19 February 1990; B, C, single vessels on 27 April 1989. The stippled line denotes the 200 nautical mile exclusive economic zone around the islands. 


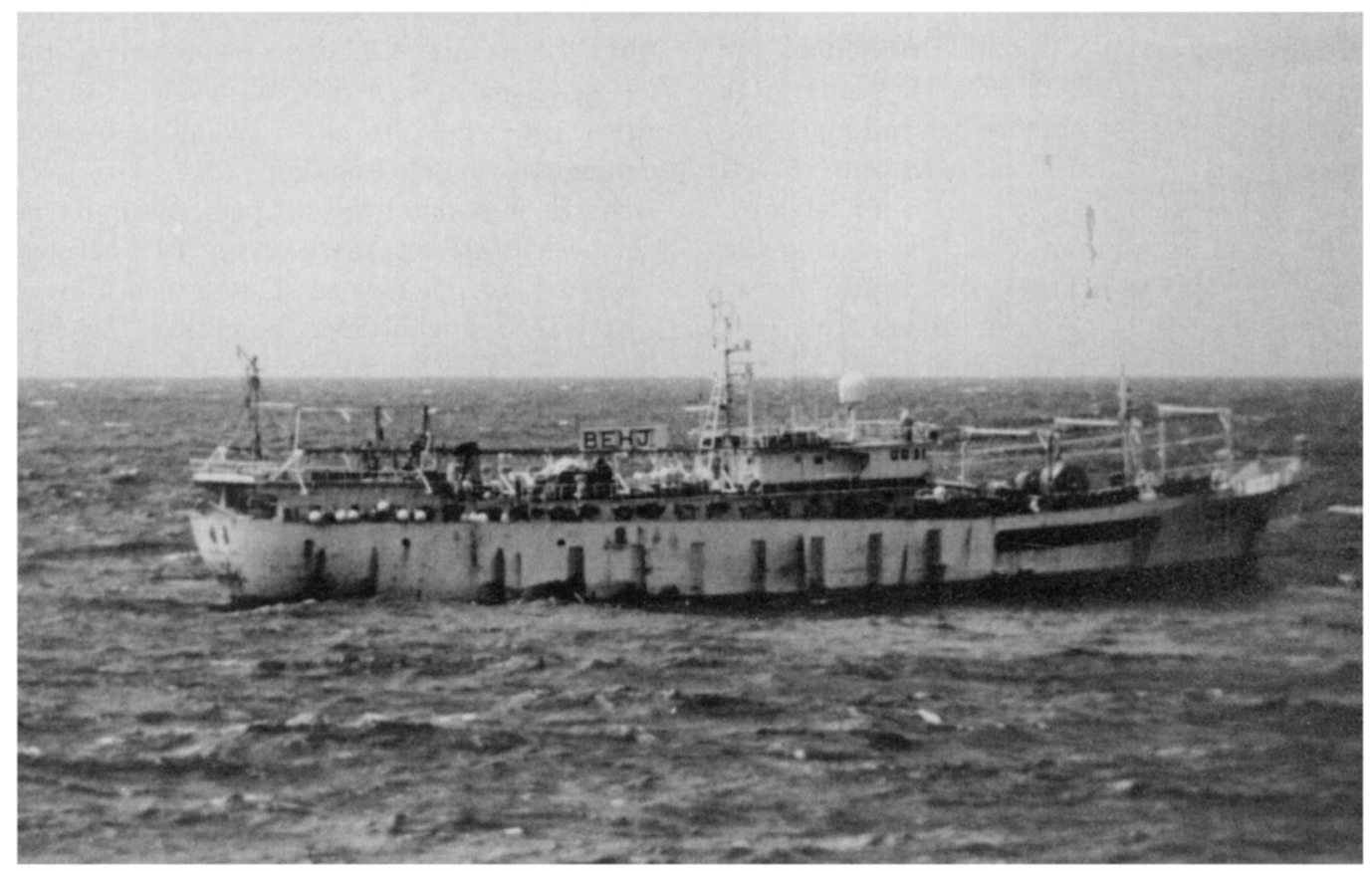

The Tuesinn Ying No. 1 fishing 150 nautical miles south of Tristan da Cunha on 19 February 1990. Eight dead rockhopper penguins were seen floating behind this vessel ( $R$. Leslie).

Argus, 21 June 1990, p. 11). Assuming that this bycatch is typical of the approximately 160 vessels apparently operating driftnets in the South Atlantic, the total numbers of non-target marine animals being killed must run into the tens of thousands.

Further direct evidence of rockhopper penguins being killed as a bycatch to the tuna fishery comes from the An-Hung 1, a Taiwanese vessel that ran aground on the South African coast on 22 May 1990. This vessel, which had a total of $145 \mathrm{~km}$ of driftnets on board, was found to have several rockhopper penguins and two subantarctic fur seals Arctocephalus tropicalis in its hold, as well as a full cargo of tuna $(H$. de Waal, Chief Directorate, Nature and Environmental Conservation, Cape Provincial Administration, pers. comm.). Three rockhopper penguins removed from the ship were adult birds of the northern subspecies E. c. moseleyi, 95 per cent of which breed at Tristan da Cunha and Gough Island (Cooper et al., 1990). Two of the three penguins were in a premoult condition, strongly suggesting that they were caught close to their breeding/moulting grounds.

This is the first time a penguin population has been threatened by incidental fishing mortality. Croxall (1990) has highlighted the potentially alarming numbers of Antarctic and Subantarctic seabirds killed by long-line tuna fisheries, but few if any penguins are affected. In the case of the long-line fishery, a simple modification to the fishing gear can greatly reduce the bycatch of albatrosses and improve fishing efficiency (Brothers, in press). However, there are at present no solutions to reduce the bycatch of marine vertebrates such as penguins in driftnets (FAO, 1990). Unless more selective driftnets can be developed, the large bycatch levels currently recorded from Pacific driftnet operations render high-seas driftnets ecologically unacceptable as a fishing technique (Coffey and Grace, 1990; Gjernes et al., 1990).

More quantitative estimates of the numbers of non-target seabirds and other vertebrates being caught in driftnets in the South Atlantic 
are required urgently. Observer programmes similar to those instituted in the North Pacific (Gjernes et al., 1990) are needed, but given the largely clandestine nature of the South Atlantic fishery, these are unlikely to be established in the near future. Consequently, given that it is considered unwise to wait for definitive data when dealing with driftnet fisheries (FAO, 1990), we believe that there is sufficient evidence to support an effective closure of Tristan waters to driftnet fisheries.

The Tristan da Cunha Fisheries Limits Ordinance of 1968, as amended by ordinance No. 3 of 1977, specifically protects an area of 200 nautical miles around the Tristan Islands, but this has had no effect in keeping illegal driftnetters from operating in Tristan waters. Diplomatic approaches to countries sponsoring driftnet fleets may produce some results, but are unlikely to be fully effective because the fishing grounds are far from governmental jurisdiction and because vessels can be re-registered under flags of convenience. For example, recent moves to restrict the Japanese driftnet fleet have resulted in some Japanese fishing companies registering their vessels in North Korea.

Ultimately, the closure of Tristan waters to driftnetters may depend upon British patrols to exclude illegal driftnetters actively. Only the concerted actions of coastal nations can bring about an effective global ban on the use of high-seas driftnets. We advocate the promulgation of an international convention for the South Atlantic Ocean, along the lines of that adopted in the South Pacific, to prohibit the use of driftnets.

\section{Acknowledgments}

We thank H. de Waal, R. Leslie and B. Rose for their observations, and R. Krohn, N. Rice and B. E. Pauncefort, Administrator of Tristan da Cunha, for information and comments on the manuscript.

\section{References}

Anon. 1989a. SA calls for action on tuna gill nets. $S$. Afr. Ship. News \& Fish. Industry Rev. 44 (6), 55.

Anon. 1989b. US salmon packers seek to curb tuna gill netters. S. Afr. Ship. News \& Fish. Industry Rev. 44 (1), 19.

Brothers, N.P. In press. Albatross mortality and associated bait loss in the Japanese longline fishery in the Southern Ocean. Biol. Conserv.

Coffey, B.T. and Grace, R.V. 1990. A Preliminary Assessment of the Impact of Driftnet Fishing on Oceanic Organisms: Tasman Sea, South Pacific, January 1990. B. T. Coffey and Associates Ltd, Hamilton, New Zealand.

Cooper, J., Brown, C.R., Gales, R.P., Hindell, M.A., Klages, N.T.W., Moors, P.J., Pemberton, D., Ridoux, V., Thompson, K.R. and van Heezik, Y.M. 1990. Diets and dietary segregation of crested penguins (Eudyptes). In: Penguin Biology (eds L. S. David and J. T. Darby), pp. 131-156. Academic Press, Orlando, Florida.

Croxall, J.P. 1990. Impact of incidental mortality on Antarctic marine vertebrates. Antarct. Sci. 2, 1.

FAO. 1990. Report of the expert consultation on large-scale pelagic driftnet fishing. Rome, 2-6 April 1990. FAO Fish. Rpt, 434, 1-78.

Gjernes, T., McKinnell, S., Yatsu, A., Hayase, S., Ito, J., Nagao, K., Hatanaka, H., Ogi, H., Dahlberg, M., Jones, L., Wetherall, J. and Gould, P. 1990. Final Report of Squid and Bycatch Observations in the Japanese Driftnet Fishery for Neon Flying Squid (Ommastrephes bartrami). June-December, 1989 Observer Program. Joint report: Fisheries agency of Japan, Canadian Department of Fisheries and Oceans, United States National Marine Fisheries Services, and United States Fish and Wildlife Service. $17+90 \mathrm{pp}$.

King, W.B. 1984. Incidental mortality of seabirds in gillnets in the North Pacific. In: Status and Conservation of the World's Seabirds (eds J. P Croxall, P. G. H. Evans and R. W. Schreiber), pp. 709-715. International Council for Bird Preservation, Cambridge.

Rice, N. 1990. Mass death in vast spider webs of the sea. S. Afr. Commercial Fisherman, 2 (3), 18-19.

Peter Ryan and John Cooper, Percy FitzPatrick Institute of African Ornithology, University of Cape Town, Rondebosch 7700, South Africa. 